\title{
Complement C3b Measurement
}

National Cancer Institute

\section{Source}

National Cancer Institute. Complement C3b Measurement. NCI Thesaurus. Code C80176.

The determination of the amount of complement C3b present in a sample. 